\title{
The New Vicissitudes of Auteur Cinema
}

\author{
By Christina Stojanova
}

Fall 2010 Issue of KINEMA

\section{THE NEW VICISSITUDES OF AUTEUR CINEMA: KARLOVY VARY 2010}

\section{The Festival and its Ambiance}

The Karlovy Vary Film Festival is a place where everyone feels at home - from the brightest stars of world cinema and Hollywood staying at Grand Hotel Pupp, to the student back-packers, who arrive in numbers every year and, in anticipation of some last minute ticket availability, squat in the hallways of Hotel Thermal, housing the festival headquarters as well as five festival film theatres. This unassuming hospitality was elegantly emphasized in the festival film vignettes, shown before each screening. Witty animation tributes to the festival president Jií Bartoška and its artistic director Eva Zaoralová, inspired by the Pink Panther and Iakov Protazanov's Aelita respectively, were paired with a series of black-and-white shorts, starring some of the most illustrious recipients of the festival's Life-Time Achievement Award, the Crystal Globe, and featuring the statuette's mostly anecdotal role in their everyday life. Andy Garcia, for example, is seen using the heavy figurine as a tool to break into his own Hollywood home; Miloš Forman grinds his night intake of medications with it. Harvey Keitel, on the other hand, explains his bandaged foot with the clumsiness of the awards presenter, who dropped the "damn thing" on his toes, and John Malkovich pulls off a hilarious gig à la Burn After Reading in response to the condescension regarding his "life-time achievement" he perceives in the remarks of his overly friendly East-Indian cabbie on the way from the airport.

\section{The Filmmaker: Power and Glory}

This year laureates of the Life-Time Achievement Crystal Globe were Jude Law and Nikita Mikhalkov. Obviously, no director could create the frenzy of a handsome male star like Jude Law, although Mikhalkov stirred up a commotion of a different kind at the press-conference he gave before the screening of his latest film, Burnt by the Sun 2: Exodus (Utomlennye solntsem 2: Predstoianie, 2010), a sequel to his Oscarwinning Burnt by the Sun (1994). Czech journalists were asking their questions with deference to one of the greatest Russian directors, but even in the most polite wording of their queries one could still discern bewilderment with Mikhalkov's latest work, or at least a thinly veiled surprise as to what burning need might have prompted his revisiting the film's nearly-perfect predecessor. Mikhalkov spoke at length, without really answering the questions, as - in a statesman-like way - he was busy addressing overtly and covertly the Russian journalists in the audience. Therefore the real purpose of his lengthy monologues remained obscure for those unaware of the on-going stand-off at the Union of the Russian Filmmakers. But for those who have come to love Russian cinema thanks to Mikhalkov's wonderful films from the 1970s and 1980s, it was painful to watch how he attributed his latest film's lack of media popularity to the attempts of Russian critics to character-assassinate him. Reminiscing about Slave of Love (Raba liubvi, 1976), Unfinished Piece for Mechanical Piano (Neokonchennaia pyesa dlia mekhanicheskogo pianino, 1977), Oblomov (1980), Dark Eyes (Ochi chernye, 1987), Burnt by the Sun (1994) and 12 (2007), I caught myself feeling guilty for judging so harshly Burnt by the Sun 2 - a film that has dragged on for so long that the very idea of it had turned into a cold turkey.

The prevailing mood of the competition films, with few exceptions, was elegiac, evolving around themes of acute alienation, sometimes resulting in total communication breakdown, and was treated in either tragic, ironic, or even parodic mode. The most intriguing for me in this sense were the Chinese Ao ge (Diago, 2010) by Chi Zhang, the Iranian Chiz-haie hast keh nemidani (There Are Things You Don't Know, 2010) by Fardin Saheb Zamani, and the Russian film Drugoje nebo (Another Sky, 2010) by the Georgian-born director Dmitri Mamulia. All three feature characters who eschew attempts to communicate their existential loneliness by sharing their yearnings with their loved ones or the friendly strangers they encounter. The fact that these films tell stories, originating in societies where traditionally the individual angst has been either repressed or dissolved vis-a-vis strong communal obligations and ties, is indicative of the overall changes these societies have drastically undergone under the pressures of Globalization. The Grand Jury Special Mentions were 
more than well deserved recognitions for Another Sky and There Are Things You Don't Know.

\section{The Competition: Existentialism and Globalization}

In a way, the identity crisis of Diago's protagonist, prompted by his mixed heritage - half Chinese, half Portuguese - is quite understandable in the atmosphere of economic, political and even ethnic confusion, provoked by the transfer of the former Portuguese colony Macao to China in 1999. The prevalent existential melancholy is strongly remindful of John Woo's most successful Hong Kong films from the late 1980s, starring Chow Yun-Fat, A Better Tomorrow (Ying hung boon sik, 1986) and The Killer (Dip huet seung hung, 1989), made on the eve of yet another Chinese colony transfer - that of Hong Kong in 1997. Woo's films - in tune of his acknowledgement of Jean-Pierre Melville's 'existential thrillers', and his direct quotes from The Samurai (Le Samourai, 1967) in The Killer - were made in anticipation of that transition, and the existential suffering of his male characters was mired in the bloody action of the classical Hong Kong thriller. As Sun Longji writes, "in Existentialism a man 'exists' by virtue of retreating from all social roles and searching his own soul. If he fails to go through this process, he cannot become a man in the philosophical sense. By contrast, a Chinese fulfils himself within the network of impersonal relationships. A Chinese is the totality of his social roles. Strip him of his relationships, and there is nothing left. He is not an independent unit. His existence has to be defined by acquaintance... In Chinese the words 'single' and 'alone' have the connotations of 'immoral' and 'pathetic'" (The Long March To Man, 1989, p. 183).

Zhang's film, on the other hand, albeit based on the Macanese writer Lio Chi Heng's eponymous novel, is made ten years after the Macao transfer, and his hero's masculinity is not dependant anymore on relationships, but is existential in a purely 'western' sense. That is, it is already possible to image him as capable of 'retreating from all social roles' by giving up his well-paid job, risking the alienation of his half-sister and Chinese mother, and embarking on a pilgrimage all the way to Portugal 'in search of his own soul.'

The same holds true of the hero of the Iranian film There Are Things You Don't Know. Ali, obviously an intelligent and educated man, but scarred by personal, professional and - as hinted - political failures, has assumed the role of passive observer of other people's lives by becoming a Tehran cabbie. This quiet film is even more anguished than Diago since Ali deliberately forfeits any and all possibilities to actively intervene in his own life, preferring to stay confined within his memories. In a way, the film could be read as a subtle criticism of Iranian intellectuals, who, in their desperation and disappointment, have chosen internal exile and passive resistance to any form of active confrontation with the regime, which has invariably repressed their desire and even ability for personal emotional commitments.

The most powerful existential drama from the competition program originates however in the Uzbek steppes, where we first meet Ali and his beguiling little boy, tending to their flock of sheep. It becomes immediately apparent that theirs is not a happy life: they collect dead sheep; their village abode is quite poor, and obviously the boy misses his mother, who, as we learn, has left them to seek a job in Moscow. We then see them leaving for Moscow, and witness the rough, humiliating 'hygienic' procedures they have to go through as migrant workers. Then comes the monotonous and harsh life in a tiny apartment, where they sleep and eat in silence, broken only by the perennial radio or TV news from the background soundtrack... But that seems unimportant as their raison d'etre in this strange big city is finding the mother... And then the boy gets accidentally killed in the wood-processing plant where he has been working. Ali bribes the warden to let him see his boy for the last time in the morgue and, again in silence, collects his meagre belongings and leaves. A few days (or weeks?) later, Ali finds the mother, and the film leaves them driving in silence through the night ahead of them... The power of this minimalist aesthetics lies in its harsh documentary realism, in its tight, claustrophobic, mostly medium to long shots, which create a growing feeling of entrapment outside of time and space. But it is the superb silent presence of Habib Boufares' Ali (the non-professional star of Abdellatif Kechiche's highly awarded film Couscous (aka La graine et le mulet, France, 2007) that is the film's most captivating element. Stripped from any and all explicit social, moral and ethnic speculations and blames to its bare existential bones, so to speak, Another Sky - the feature film debut of the obviously very talented director and script-writer Dmitri Mamulija - comes as close as they come to that so much cherished festival discovery.

\section{The Competition: Between Auteur and Commercial Cinema}

From the films, made in the West, the one that comes closest to the repressed emotional states of the 
heroes, discussed above, is Daniel Burman's Dos hermanos (Brother 86 Sister, 2010, Argentina-UruguaySpain). The ageing siblings are caught in medias res, as it were, in their on-going destructive symbiosis, where the 64-year-old Marcos is the perennial victim of his irresponsible and egotistic younger sister. After a series of insignificant, sometimes hilarious antics, where - in addition to taking loving care of their ageing mother - Marcos is being used in Susana's schemes to play a high-class lady, she finally succeeds in the big one. And, after the death of their mother, tricks her grief-stricken brother out of his home and, what is more, out of the money she gets from its sale. Gradually but surely, however, the viewer's attention shifts from the arrogant Susana to Marcos and to the gentle way he deals with his pent-up Oedipal drama and sibling complexes. But instead of leaving it to Antonio Gazalla's talent (and to the viewer) to grasp the delicate nuances of Marcos' belated attempts to grow out of this cobweb of repressed emotions after moving on his own in Uruguay, or to express his frustration by proxy while acting in Oedipus Rex, staged by the local amateur theatre, the director-script writer has him dot all i's and cross all t's in confessional talks with the theatre director. These clarifications, included in a misguided concern for the viewer, coupled by the equally redundant happy reunion of brother and sister, drastically lessen the effect of what could have been an excellent chamber piece.

The family angst at the centre of the subsequent three films under scrutiny - Olivier Coussemacq's L'enfance du mal (Sweet Evil, 2010, France), Pawel Sala's Matka Teresa od kotow (Mother Teresa of Cats 2010, Poland) and Catherine Martin's Trois temps après la mort d'Anna (Mourning For Anna 2010, Canada), looks artificial and at times sensationalist. Probably this is the unwarranted side effect of the inevitable tensions between the natural authorial drive (all three films are scripted by their directors) for originality, on one hand, and on the other - the requirements of the money-giving institutions and distributors.

The belief that audiences take seriously any traumatic psychological situation only if taken to its extreme, and even to sheer depravity, has turned into truism. It seems to have inspired Olivier Coussemacq, the author of the debut drama L'enfance du mal to keep hinting heavily on the possibility - if not on the reality - of teenage sex to prop up his otherwise rather unusual story of lies and betrayal. In the course of her unclear pursuits, the teenage squatter Céline seduces the owner of the shed she has 'moved in' - a middle-aged, powerful judge, wrecks his marriage and indirectly causes his death. True, the sex scenes are referred to sparingly, but unequivocally, thus violating the prevailing mood of duplicity and double-crossing. Albeit disguised as a sacrificial offering by the young heroine in exchange for her beloved mother's freedom from a wrongful prison sentence, delivered once by the judge, the lurking ghost of depravity sticks out as a blatant commercial device, undermining the film's authorial component - the moral ambiguity of narrative and characters. The commercial effect, however, is in its turn diminished by the film's cold, even alienating, elegant visual artifice and by the fact that the characters of the judge, his wife, Céline and even of her victimized mother, are designed with unusual coldness, void of any and all sympathy. And it has therefore remained unclear whether the main jury wished to encourage the auteurist or the commercial tendencies, displayed in Coussemacq's film, by bestowing the Best Actress Award to Anaïs Demoustier for her quite bland performance as Céline.

The Polish debut feature Mother Teresa of Cats begins promisingly, with the fast-paced arrest of two brothers, shot and edited with unique expressiveness and energy. Moving methodically in reverse chronology from the present time of the arrest to earlier story events - in itself an original structural device - the film reveals a family tragedy rife with Oedipal tensions and sibling rivalries, catalysed by the ineffective and confused presence of a traumatized and weak paterfamilias, who has the notorious privilege to have been one of the few Polish soldiers to participate in the Iraq war. Even such a brief overview reveals a narrative, overloaded with trendy, even sensationalist issues. However, the further back the film moves, the less comprehensive psychologically the brothers' degeneration into the cruelty of matricide becomes... The sweet, but passively ambiguous presence of Ewa Skibiska as their mother, makes things even more confusing: do they kill her because they believe she loves her cats more than her sons, or is it a result of pathological jealousy of her, or is it a way of punishing her for being so loyal to their good-for-nothing father? The title of the film, rife with promising references to a couple of great Polish film - Jerzy Kawalerowicz Mother Joan of the Angels (Matka Joanna od aniolów, 1961), based on the intense horror story by Jaroslaw Iwaszkiewicz of mystical possession and exorcism in a $17^{\text {th }}$ century nunnery, and Janusz Zaorski's Mother of Kings (Matka królów, 1987), one of the jewels of the post-Solidarity Cinema of Moral Concern, venturing boldly into the forbidden 
territory of the early Communist purges from the second half of 1940s - does not help one either to decipher the meaning of this otherwise intriguing film. In any case, the Best Actor Award, given ex aequo to Mateusz Kosciakiewicz and Filip Garbacz for the roles of the two murderous brothers, obsessed with psychotronics and übermensch complexes, was quite well deserved.

\section{Theme with Variations: The Canadian Participation}

The Canadian competition entry, Trois temps après la mort d'Anna (Mourning For Anna, 2010), by Catherine Martin, raises the emotional stakes even higher, inviting us to witness the raw suffering of Françoise, who has just lost her gifted and vivacious violinist daughter to a deranged killer. And although Guylaine Tremblay, one of the bright stars of Quebec cinema, is fantastic as Françoise, her psychologically nuanced acting brilliance makes the film even more challenging to watch! Comfortably well-off and well taken care of by a loving husband in the city and by an old flame - a successful artist, who still happens to be in love with her - in the country, Françoise has the unique privilege to abandon herself to her all consuming grief in the seclusion in her stylish country home. And it is exactly this attempt by the writer-director to show the existential nakedness of Françoise's agonizing grief, undisturbed by any and all everyday chores and worldly problems, where this otherwise well-crafted film loses touch with reality and with the viewer. Yet because of Tremblay's superb acting and especially because of the powerful scenes, where she evokes the ghosts of her long suffering - and very religious - mother and grandmother to help her through her ordeal, the film remains on this side of auteur cinema and does not degenerate into yet another tear-jerker, where "the rich also cry".

Moreover, Mourning For Anna had its unique place amongst the Canadian films, presented at the festival, especially in-between the other auteur film from Quebec, the debut feature Jaloux (Suspicions, 2010), a psychological thriller by writer-director Patrick Demers (presented by the Forum of Independents), and Chloe (2010), the star-studded, Hollywood-inspired and financed high-class melodramatic thriller (shown in Horizons), whose only Canadian components are its director Atom Egoyan and the Toronto location.

The fourth Canadian film, Tucker $\&$ Dale vs. Evil (presented in Another View) - an inventive parody of slasher movies, more specifically, of the iconic Texas Chainsaw Massacre (1974) - is, on the other hand, entirely financed by Canada, but directed by the young American Eli Craig. From the steady Canadian presence at the festival over the last half-a-dozen of years or so, and on the basis of this year's entries in particular, one could deduce - and rightfully so - that while the young English-Canadian cinema seems to become increasingly interchangeable with the independent American, the cinema from Quebec sustains its own unmistakable physiognomy. And yet, the Canadian-ness of such diverse films in mood and genre as Mourning For Anna, Suspicions and Tucker 83 Dale - whether produced in Quebec or outside of it - is encoded in the unique role they assign to Nature. Apart from its conventional romantic understanding as 'Mother Nature' - the soothing presence Françoise turns to in the most tragic moment in her life, or the misguided and self-destructive fright of the wilderness, displayed by a bunch of hopelessly urbanized and technologically spoilt college kids in Tucker $\& 5$ Dale, Nature has also been playing an increasingly important - predominantly menacing role in recent Quebec films by young directors. For one, Denis Côté film Nos vies privées Our Private Lives, 2007, comes immediately to mind. Seen as a catalyst of the characters' inner turmoil, the representation of Nature as harbouring mortal dangers could also be defined in psychoanalytical terms as externalization or projection of repressed fears and atavistic desires, buried in the unconscious.

In Suspicions, for example, Thomas and Marie go to the country house of the boy's uncle in order to mend their relationship, strained on account of Thomas' jealousy. In the cabin they meet a strange man and spend the night with him, eating the dinner he has cooked and getting quite drunk on his wine. On the next day, however, when piecing together the events from the previous night, Thomas comes to the conclusion that while he dozed off in his drunken state, Marie has had an orgiastic sex with the stranger. While trying to figure out who the man is and what is his game, Marie and Thomas gradually patch up their relationship by ganging against the stranger and ultimately killing him, only to find out that he never slept with Marie, and was actually stalking his ex-wife, who happened to be Thomas' uncle's girlfriend. Indeed, as Marie says, nothing could hold two people together better than a dangerous secret!

In addition to the dramatic ingenuity of the film, which relies heavily on its brilliant editing and the impeccable presence of the young actors, the film is astonishingly honest in its moral ambiguity, displayed not 
only by the characters, but also by the director with regard to the murder. An ambiguity, enhanced and justified by the menacingly calm presence of Quebec's half-tamed wilderness. The stranger with his imagined guilt represents the ultimately uncanny materialization of the 'other'. That is, a projection of Thomas' most intimate fears that his girlfriend could betray him when drunk, and of Marie's phantasmic desires of being raped while drunk. Unleashed from the depths of their own repressed human nature, which is becoming tragically inaccessible for their materialist and technology-saturated generation, these projections become even more compelling and uncontrollable amidst the solitude of the equally frightful outside Nature.

\section{The Competition: Family Feuds in Comedic and Absurdist Mode}

Ubiquitous heterosexual promiscuity is usually the stuff comedies of manners are made of. Not unlike its great predecessor Jean Renoir's archetypal comedy of manners The Rules of the Game (1938), the Croatian entry Neka ostane među nama (Just Between Us) by veteran director Rajko Grlić pokes fun at the irresponsible hedonism of its characters. While sympathetic to the director's attempt (or need) to make a marketable product, relying entirely on sex, but knowing his wonderful films from more than 30 years ago, Bravo, Maestro (1978) and You Only Love Once (Samo jednom se ljubi, 1981), I was impatiently waiting for the moment when he would reveal his true intentions. That is, take this accumulation of sex ad nauseam to some other level - that of a social satire or absurdist comedy, or anything that would justify Grli's name in the credits as both scriptwriter and director. On the eve of WWII, while Renoir implied heavily and prophetically that his characters' nonchalance was a sign of serious social malaise with potentially tragic consequences, Grli simply identifies with the sexual athletics of Miki Manojlović's over-successful businessman Nikola, caught up between his young wife, his mistress, old and new flames. Thus the film remains on the level of the perennial sexual rivalry of Nikola and his younger brother, and the intertwined (and, shall I say, interchangeable) string of women in their lives. Small wonder then that the Best Director's Award Grlić received raised a few eyebrows.

Against this backdrop, the Spanish La mosquitera (The Mosquito Net, 2010) by writer-director Augusti Vila comes through as a kind of philosophical reprise of the main theme, where the family crisis could be read as a grand metaphor of our dysfunctional Western world. The growing number of saved pets - mostly dogs, but also birds and cats - in the apartment of this middle class family of three, uncannily reminds one of the cats, cluttering the much smaller apartment in the Polish film Mother Teresa of Cats, but expressing in similar visual terms the growing alienation and communication breakdown amongst the family members. The contrasting attitude toward the pets each of them harbours - either hostile or friendly - becomes part of their overall characteristics. Alice, the overly protective mother of the teenager Luis, for example, is as lenient to the pets he keeps bringing home as she is to his drug addiction, while her husband Miguel - a nice, but weak man, totally oblivious to Luis' problem - is making feeble attempts to convince Alice that they should put a limit on the number of pets they could keep at home. The turning point comes on Luis' birthday, when - led by her desire to play her son's friend rather than his mother - Alice becomes infatuated with his school-friend. True, as is to be expected, her flunk ends up quite quickly in humiliation, but even her husband's extramarital shtick with their charming cleaning lady, albeit harbouring a much more serious potential, tumbles in emotional disaster because of his unwillingness or ineptitude to take responsibility. And yet these bitter experiences fail to make Luis' parents any wiser or helpful.

Unlike the last five competition films, discussed above, The Mosquito Net remains consistently elusive and ironic, sustaining its tongue-in-cheek attitude by saying as little as possible, and offering the viewer very few explicit clues about its multiple layers of meaning. Yet in order to exonerate to a certain extend the infantile indecisiveness of Alice and Miguel, and orient somehow the viewer in this maze of moral laissez-fairism, Vila has included another, seemingly unrelated plot line - that of Alice's sister, torturing her little daughter into submission by setting with astonishing cruelty the limits, which Alice fails so spectacularly to do with regard to her family. On the other hand, the silent presence-de-clef, so to speak, of Geraldine Chaplin as Maria, Miguel's Alzheimer-stricken mother, harks back to her powerful films about dysfunctional families from the 1970s, made with Carlos Saura, whose intellectual heir Vila might be considered. On a philosophical level, her Maria is also a tragic reminder of the vanity and brevity of it all, whether functional or dysfunctional. And yet, whatever explicit message The Mosquito Net is trying to convey - if any - it pales before the elegant wit with which it goes about it. A well deserved Crystal Globe.

\section{Theme with Variations: The Czech Program}


Understandably, the program of Czech films was rich and diverse. Alongside films by first-time fiction film directors, it also contained films by well-established and highly-acclaimed directors from the Czech new New Wave of the 1990s: Jan Svěrák's Kooky (Kuky se vrací, 2010), Jan Hřebejk's Kawasaki's Rose (Kawasakiho rüže, 2009) and Tomorrow there will be... (Zítra se bude ... 2010), and Irena Pavlásková's An Earthly Paradise for the Eyes (Zemský ráj to na pohled, 2010). The Czech program also featured works by documentary directors, such as Helena Třeštíková's Katka (a second instalment in the saga of a girl, trapped by her own addiction, whom Třeštíková has been observing for more than fourteen years now) and Filip Remunda and Vit Klusák's Czech Peace (Český mír, 2010).[1]

The prevailing concern of the main competition was to capture the state of affairs of auteur cinema, preferably first or second films, produced on three continents by young and not-so-young directors. One of the two Czech entries, 3 Seasons in Hell (3 sezóny v pekle, Czech co-production with Germany and Slovakia, 2010), by writer-director Tomáš Mašín, stood quite apart from the contemporaneous existentialist concerns of his colleagues from Iran, China and Russia and their search for spiritual values and identity amidst broken families and personal tragedies in an increasingly globalizing world, where everything goes, nothing matters, and materialism runs high.

Mašín's film is based on The First Ten Years, the autobiography of the recently deceased writer and philosopher Egon Bondy, one of the most controversial figures in the Czech intellectual world since his turbulent youth in the late 1940s. The film is representative of a renewed interest of young Czech cinema in the country's WWII history and its immediate aftermath - an interest that could be described as truly postmodern, flaunting all textbook characteristics of post-modernity - pastiche and intertextuality of the narrative, as well as baroque opulence of the visuals. The film's slick visuals, meticulously designed in golden-brown are a throw-back to Mašín's career as a production designer and multi-media artist, as well as to the fashionable retro-style of the 1970s, popularized by such cinematic landmarks as Bernardo Bertolucci's 1900 (Novecento, Italy, 1976) and Jack Clayton's The Great Gatsby (US, 1974). Its impeccable professionalism and taste notwithstanding, the visual excess of 3 Seasons in Hell tends to undermine the raw drama that befalls the intellectual circle of young iconoclasts when post-war Czechoslovakia falls into the grip of Kremlin in the late 1940s. The filmmakers' infatuation with Art Nouveau interiors, gorgeous Prague exteriors, the elegant clothes and bohemian lifestyle of beautiful young people, equally enthusiastic about free love and raising hell as they are about Marxism, Anarchism and Communism - all this eschews the much-needed psychological depth. Thus the message of Bondy's book - the tragic disillusionment of a generation devastated by a regime whose advent they have themselves unwittingly facilitated - fails to rise up to the energy levels of the hedonistic episodes. The growing sense of guilt of the young protagonist Ivan Heinz (Kryštof Hádek) in the face of his and his friends' moral, psychological and physical destruction at the hands of Communist henchmen, rings somewhat hollow.

Protektor (2010) by Marek Najbrt, another historical film, applies a similarly overbearing aesthetic mode to yet another major national tragedy - that of the persecution of Jews during the occupation, exacerbated by the assassination of Nazi Reichsprotektor Reinhard Heydrich in May 1942. At the centre of the film stands the moral disintegration of Emil, a famous national radio host, who - for the sake of his career - betrays his beloved wife Hanna, a budding film star of Jewish origin. Again, the emerging trend of visual indulgence and sensationalism - rear projections, inventive in-sets of film excerpts and elaborate drug-inspired visions, justified by the fact that Hanna's real protector, the projectionist of a nearby film theatre, offers her not only free access to the movies but also drugs - reigns at the expense of psychologically convincing characters and a meaningful drama.

The fashion for visual gimmickry has affected even such a staunch supporter of good old storytelling as the Oscar-winner Jan Svěrák - in the first film he has scripted himself, without his father Zdeněk Svěrák's participation. Although Kooky is a predominantly successful experiment in the seamless blending of CGI with traditional puppet animation, he nonetheless relies mostly on dialogue to tell the story of the fluffy little doll who, after being dumped, makes a journey back home to his friend Ondra, played by the director's young son Ondřej. Whether Kooky's ecological message about the values of clean air and true friendship reaches its potential audience - young children and their parents - remains to be seen, but the Special Jury Prize was a definitely deserved recognition of the new - or rather forgotten - path Sverák embarked on with his 1994 elegantly-ironic venture into the world of Sci-Fi with Akumulátor 1. 
The biggest disappointment in terms of the treatment of traumatic events from Czech history came from Hřebejk's Kawasaki's Rose, another collaborative effort with screenwriter Petr Jarchovský. Straddling between contemporary events and the communist "normalization" bracketed by 1968 and 1989, the film seems like a not very inspired reworking of themes that have dominated Hřebejk's and Jarchovský's oeuvre since Cosy Dens (Pelísky, 1999), the most spontaneous and inspired expression so far of their penchant for a close examination of the idiosyncrasies of the Czech family under the pressure of history: first communism; then, in Divided We Fall (Musime si pomáhat 2000) - Nazism; and in Up and Down (Horem pádem, 2004) post-communism.

Unlike Bohdan Sláma and Petr Zelenka, however, who prefer the dark-ironic, absurdist and even sarcastic rendition of family stories, Hřebejk seems to take himself seriously and, after the more or less unsuccessful flirt with comedy of manners Beauty in Trouble (Kráska v nesnázích, 2006), has adopted the path of a latter-day preacher, whose favourite sermon is on the moral superiority of dissent over conformism, of loyalty over betrayal. There would be nothing wrong with this choice, if his moral righteousness were concerned less with the historical virtue of dissent - his favourite theme since Pupendo (2003) - and more with its power to deflect the destructively insidious form of the new "normalization" - that of capitalist greed gnawing on traditional Czech values. There is indeed something overbearing and even haughty in the righteousness of his main character, the internationally famous photographer and photojournalist Antonín Kratochvíl (playing himself in the film, albeit under different name). His moral resilience under communism is presented with a kind of halo, which makes one immediately think of the compromises he inevitably had to make in order to establish himself as an émigré celebrity in one of the most hard-nosed professions in the West. A healthy doze of antidote to this noisy litany to historical dissent and silent endorsement of current conformism was provided by the documentaries, Czech Peace - a sarcastic commentary on the pros and cons on the now defunct project of building an American radar base in the country - and especially Katka, revealing the flip-side of the myth of perennial happiness and freedom for all, secured by the free-market and democracy.

Tomorrow There will be..., an opera by Aleš Březina (with Jiří Nekvasil), the composer for most of Hřebejk's films, offers a much better rendition of the horrors of the Communist past than most fiction films. Titled ironically after one of the most atrocious Stalinist musicals made in Eastern Europe, Vladimír Vlček's film Tomorrow, There Will Be Dancing Everywhere (Zítra se bude tančit všude 1952), the filmed show tells in minimalist manner, and subdued colours the tragic story of the trial that sent to the gallows a member of the official anti-Communist opposition in the Czechoslovak Parliament, Dr. Milada Horáková (in the exquisite interpretation of Soňa Cervená, the grande dame of Czech opera) in 1950.

In fact, Irena Pavlásková's An Earthly Paradise for the Eyes (FIPRESCI Award and Best Actress award for Vilma Cibulková at the Moscow Film Festival 2010) refers (under aliases) to some of the top Czech dissidents, including actor Pavel Kohout and writer Václav Havel. Based on the memoirs of Pavel Kohout's daughter Tereza Boučková, it became such a success thanks to its meticulous retro style, psychological authenticity, nostalgic romanticism and, above all - the absence of pretence.

The FIPRESCI favourite, Hitler in Hollywood, a mockumentary about an alleged Hollywood scheme to destroy both art cinema and popular European cinema, written and directed by the Belgian film theorist and historian Frederic Sojcher, hits dangerously close to home. Especially for those who are familiar with, among others, Jean-Luc Godard's Histoire(s) du cinéma and their passionate anti-commercial sentiment, laying directly at Hollywood's door the blame for corrupting the film image by rendering it meaningless through oversaturation of the cultural space. While it is true that Sojcher's inside jokes could be grasped in their entirety only by serious film buffs (like the one about Raoul Coutard being a CIA agent), Hitler in Hollywood is widely accessible on many other levels. Maria de Medeiros - the French actress made famous by Pulp Fiction - as the idealistic and enthusiastic investigative TV reporter, for one, is an excellent bridge between the viewers and the unravelling mystification about some lost film, made in 1939 by a fictitious filmmaker, Luis Aramcheck, with the real-life French actress Micheline Presle, who plays herself in the film. The closer to finding the lost film Medeiros and her cameraman get, the more dangerous obstacles, implicating the Gestapo, CIA and MI5, they have to face. In the process, they interview celebrities like Wim Wenders and Emir Kusturica, who passionately hail their efforts to save an European art cinema artifact from the clutches of Hollywood. 
Hitler in Hollywood could be seen as a witty commentary - or mise-en-abîme - on the state of affairs not only of European auteur cinema, but also of auteur cinema worldwide as presented at the $45^{\text {th }}$ edition of the Karlovy Vary Film Festival, whose competition featured twelve auteur films, four of which debuts. And while some of those works (Another Sky, There Are Things You Don't Know, Zhang Chi's Diago, The Mosquito Net) adhere uncompromisingly to the principles of art cinema, established by modernist cinema from the 1960s and 70s, others (Brother \& Sister, Mourning For Anna) borrow devices from popular Hollywood cinema to bring their message closer to the viewer, yet others (Sweet Evil, Mother Teresa of Cats, Just Between Us, 3 Seasons in Hell) espouse misguided and even counterproductive narrative or visual sensationalist approaches, which undermine considerably their originality. Indeed, one cannot think of a more appropriate film message, commenting on the ever-so-strenuous relationship between art cinema and commercial cinema, between Hollywood and small national cinemas, than this of Hitler in Hollywood. And luckily delivered at the right time and place - the Karlovy Vary International Film Festival 2010.

\section{Author Information}

Christina STOJANOVA teaches at the Department of Media Production and Studies at the University of Regina, Canada. She has contributed to Cine-bulles, KinoKultura, and the Montreal Gazette. Her publications include chapters in Berlin Culturescapes, Making it Like a Man: Canadian Masculinities, Eastern

European Cinema, Traditions in World Cinema, Horror International, Alternative Europe and Cinema and Globalization. 